\title{
Education in Turkey in terms of gender asymmetry
}

\author{
Fatih Düzgün ${ }^{1^{*}}$, Eda Havva Tan Metresh ${ }^{1}$, Alina Aleksandrovna Pozdnyakova ${ }^{2}$, Tatiana \\ Stanislavovna Grafkova ${ }^{3}$, and Marina Evgenievna Kalita ${ }^{4}$ \\ ${ }^{1}$ Akdeniz University, Department of Russian Language and Literature, Antalya, Turkey \\ ${ }^{2}$ The Kosygin State University of Russia, Institute of International Education, Moscow, Russia \\ ${ }^{3}$ Moscow Pedagogical State University (MPGU), Department of German, Moscow, Russia \\ ${ }^{4}$ Moscow Pedagogical State University (MPGU), Department of English and Digital Educational \\ Technologies, Moscow, Russia
}

\begin{abstract}
The wide representation of women at different levels of the education system is not only an indicator of the prestige and status of the teaching profession, but also an important indicator of the socio-cultural and political development of society. The purpose of this article is to analyze the Turkish education system in terms of gender asymmetry. The research problems include: 1) the study of the historical reasons that led to the phenomena of gender asymmetry in certain "zones" and at certain levels of education; 2) the study of the motives for choosing a teaching profession by women of different age groups; 3 ) determination of the social profile of a Turkish female teacher; 4) the formation of recommendations for overcoming gender asymmetry in the field of Turkish education. Contrary to prejudice, Turkey is not a "gender bounded" country; moreover, its educational system is subject to problems common to the systems of most developed countries. The main ones are: 1) underrepresentation of female teachers in higher education (with a tendency to reduce the gender gap) and 2) underrepresentation of women in leadership positions. Despite the fact that all conditions have been created in Turkey for the professional development of a female teacher, the mentality of the average Turkish woman does not allow her to put her career interests above the interests of her family. This, in our opinion, largely explains the "restriction" of female education at the level of secondary specialized and insufficient "popularity" of higher education. For further study of the manifestations of gender asymmetry, a more detailed study of all stages of the Turkish education system is required, using data from different regions, in particular, from the southeast region. The situation there may differ significantly from the situation in the central regions, and the problem of adapting the education system to regional conditions will be extremely relevant.
\end{abstract}

Keywords: gender asymmetry, education system, education of women, Republic of Turkey

\footnotetext{
* Corresponding author: apozdnyakova@live.ru
} 


\section{Introduction}

The concept of gender asymmetry means "a social phenomenon that reflects the objective regularity of the quantitative distribution of men and women in the social structure of society and in all spheres of its life, as well as the qualitative social consequences of this phenomenon" [1]. Such features of this phenomenon as "objectivity" and "regularity" are considered to be important in the definition of Sillaste, since they reflect the natural character of the development of disproportionate relations in a particular sphere of human interaction. It is from these positions that authors would like to consider the situation observed today in the Turkish education system.

\section{Methods}

To determine the range of reasons causing gender asymmetry in the education system of the Turkish Republic at certain stages of its development, an analysis of psychological, pedagogical, sociological, historical and philosophical literature was carried out. The following works of Turkish authors should be noted: Akyüz [2-4], Yaşar [5], Çakmak [6], Eşkinat [7, 8], Aydın [9], Tor [10], Güven [11], Sargın [12]; the research of Russian author Sillaste is highly relevant $[1,13,14]$.

The information base for the analysis was data from open sources: 1) analytical reviews on the problems of economic and social development of regions [15-17]; 2) summarized statistical data related to the study of the teaching staff on teaching and learning [18-22];3) materials of websites of Turkish educational institutions.

To confirm the assumptions put forward regarding the nature of gender asymmetry in Turkish education, a survey of teachers in Turkish institutions of primary, general secondary and higher education, as well as women leaders who organize and supervise education was conducted.

\section{$3 \quad$ Results}

The wide representation of women at different levels of the education system is not only an indicator of the prestige and status of the teaching profession, but also an important indicator of the socio-cultural and political development of society.

For modern Turkey, these indicators are quite positive and comparable to those of many European countries (see Table 1). According to 2016 data, the proportion of women in the total number of teachers (HEI teachers) is at the border of $60 \%$ for primary and basic general education - the levels of education that are extremely feminized in Europe and traditionally defeminized in Muslim countries [22].

Table 1. Comparative representation of women in education.

\begin{tabular}{|l|c|c|c|c|}
\hline $\begin{array}{c}\text { Country / education } \\
\text { levels }\end{array}$ & $\begin{array}{c}\text { Primary } \\
\text { general } \\
\text { ISCED 1, \% }\end{array}$ & $\begin{array}{c}\text { Basic general } \\
\text { ISCED 2, \% }\end{array}$ & $\begin{array}{c}\text { Secondary } \\
\text { general } \\
\text { ISCED 3, \% }\end{array}$ & $\begin{array}{c}\text { Secondary } \\
\text { vocational and } \\
\text { higher } \\
\text { ISCED 5, 6, 7, 8, \% }\end{array}$ \\
\hline Turkey & 59.5 & 58.9 & 50.4 & 43.3 \\
\hline The Czech Republic & 94.4 & 77.8 & 62.7 & 38.4 \\
\hline The Netherlands & 86.7 & 52.5 & 52.6 & 45.2 \\
\hline Russia & 99.4 & - & 83.7 & 63.4 \\
\hline
\end{tabular}


Remembering the history of female education in Turkey, the authors note that formerly primary schools were the only educational institution where girls could receive education. With the creation of the Turkish Republic in 1924, emphasis was placed on the democratization of education. The founder of the Turkish Republic, Mustafa Kemal Ataturk, believed that by providing women with equal right to education, it would be possible to find ways to solve social problems, however, according to researchers, "inequality in the application of laws was a clear sign of the latent patriarchy of modernism against the open patriarchy of traditionalism" [7]. This duality in the implementation and perception of socio-cultural reforms influenced the formation of the historical consciousness of the Turkish woman and determined the social profile of the modern teacher.

The modern Turkish female teacher is:

1) a woman with a secondary vocational education (ISCED 5), since a higher level of education for women "is not associated with increased employment opportunities" [23]. The researchers note that employment in the system of preschool (ISCED 0), primary general (ISCED 1) and secondary general (ISCED 2) education require the specified level of teacher's education is sufficient, and the unemployment rate is minimal, while in the higher education system (ISCED 5, 6, 7) the unemployment rate is constantly increasing;

2 ) a quite young woman; according to the OECD, the percentage of teachers under 30 working in the primary and secondary school system is particularly high $(18 \%$, rating $3 / 36$, 2018), while the percentage of teachers over 50 in this area is $12.4 \%$ (rating $36 / 36,2018$ );

3) a woman who is more oriented towards work in the public sector. In our opinion, this is due to two reasons: first, the fact that in the public sector the ratio of women's wages to men's wages is slightly higher than in the private sector -0.783 and 0.767 [15]; secondly, the fact that this work is better combined with family responsibilities (shorter working hours, normalized working hours, etc.) and allows a woman to be in demand both at work and at home, which is extremely important for a Turkish woman;

4) a woman with a traditional family, although in recent years the number of unmarried women has also increased, especially in the field of higher education. Moreover, Turkey is a country where "the type of egalitarian family is recognized and supported by national legislation" [14];

5) a woman who does not actively strive for a career, but cares about improving the quality of the existing education, therefore, participating in various additional training programs;

6) a woman who is more focused on research in the natural sciences; the number of women focused on social sciences, economics is less [23]. This fact is confirmed by statistics on the number of women who completed doctoral studies [18-21]. Thus, the proportion of women who have completed doctoral studies in natural sciences, mathematics and statistics is quite high and amounts to $57.7 \%$ (rating $4 / 43,2018$ ).

The main reasons for choosing the profession of a teacher (HEI teacher) by Turkish women include the following:

1) The high status of the teaching profession in society, respect for the people of this profession. According to surveys of teachers in Turkish schools of different levels of education, the attractiveness of the profession is significant for $68 \%$ of respondents.

2) Sufficient, in the opinion of the respondents, the level of state support for education: $27 \%$ of teachers indicated satisfaction with this parameter, $43 \%$ indicated partial satisfaction, $7 \%$ of respondents expressed dissatisfaction with the level of state support, $23 \%$ found it difficult to answer the question. The data from related studies show that 
among those financed from the state budget, the teaching profession is one of the most well-paid and socially protected.

3) Sufficient level of education. As we indicated above, secondary vocational education is sufficient for the implementation of pedagogical activity at all levels of the education system, except for higher education. This allows a woman, after graduating from college, to start working in her specialty, while the lack of higher education is not an obstacle to certain career growth. Turkey has one of the lowest proportions of women completing tertiary programs $(52.8 \%, 33 / 36$ in 2018) among OECD and partner countries for which data are available.

4) Lack of gender "confrontation" in this area. Up to half of the teachers in Turkish schools are men, and this parity largely determines the quality of professional interaction in the education system. In addition, in education, women and men receive almost the same wages. According to statistics, women's earnings as a percentage of men's earnings (among people aged 25 to 64 with higher education and income from work) is one of the highest among countries for which data are available $(83.6 \%$, rating $3 / 37,2017)$.

The results of the survey confirm the assumption that the choice of the profession of a teacher (HEI teacher) for a Turkish woman in most cases is deliberate and largely based on deep motivation: a woman correctly evaluates her abilities in terms of combining work and family responsibilities, she knows well the content of the activities that she has to exercise, and feels confident enough in this area.

\section{Discussion}

According to the classification of Sillaste, Turkey belongs to the type of countries "gender symmetric, with parity of males and females in the structure of the population (50 to 50\%)" [14]. In addition to Turkey, this group includes countries of "European orientation" Australia, Greece, Denmark, Canada, Norway, Sweden, as well as the Republic of Korea, Tajikistan, Turkmenistan, Uzbekistan. Statistical data and analytical reviews make it possible to form an idea of the degree of women's involvement in education (see Table 2). The share of women at different levels of the educational system (from ISCED 1 to ISCED $5,6,7,8)$ in the countries of the first subgroup is consistently decreasing [22].

Table 2. The share of women in education.

\begin{tabular}{|l|c|c|c|c|}
\hline $\begin{array}{c}\text { Country / education } \\
\text { levels }\end{array}$ & $\begin{array}{c}\text { Primary } \\
\text { general } \\
\text { ISCED 1, \% }\end{array}$ & $\begin{array}{c}\text { Basic general } \\
\text { ISCED 2, \% }\end{array}$ & $\begin{array}{c}\text { Secondary } \\
\text { general } \\
\text { ISCED 3, \% }\end{array}$ & $\begin{array}{c}\text { Secondary } \\
\text { vocational and } \\
\text { higher ISCED } \\
5,6,7,8, \%\end{array}$ \\
\hline Greece & 71.4 & 66.5 & 55.7 & 33.8 \\
\hline Canada & 74.5 & - & 74.5 & 49.0 \\
\hline Norway & 74.6 & 74.6 & 53.2 & 45.7 \\
\hline The Republic of Korea & 78.1 & 69.9 & 52.8 & 34.9 \\
\hline Sweden & 76.9 & 76.8 & 53.4 & 44.5 \\
\hline Turkey & 59.5 & 58.9 & 50.4 & 43.3 \\
\hline
\end{tabular}

If we consider the countries of the second subgroup (Tajikistan, Turkmenistan, Uzbekistan), which became part of the Russian Empire in the middle of the 19th century, and then into the USSR, and therefore experienced a strong influence of the Russian educational tradition, then there is a similar trend: the share of women at all levels of education is about $70 \%$ with a significant decrease in higher education [24]. 
An interesting observation is that, despite different cultural, historical and educational traditions, countries are converging at the point of belonging to a "gender symmetric" group, while maintaining the essential characteristics of the ethnic education system. However, the large area of Turkey and its wide length from west to east implies the heterogeneity of the distribution of human resources and the different quality of education and educational services: the poor and backward southeastern regions are characterized by a strong influence of patriarchal religious and cultural traditions and significant manifestations gender asymmetry. According to Sillaste, "gender inequality inhibits human development; the average level of achievement in a particular country cannot be adequately assessed without taking into account the inequality between men and women" [14], so the development of recommendations to overcome gender asymmetry in the field of Turkish education is of high importance.

\section{Conclusion}

In our opinion, the balance between education and employment should be revised taking into account new programs targeting women in specific regions, including in the private sector. While the public sector is the main platform for employment of women, the private sector requires support by creating the conditions for hiring more women, reorienting tax policies, insurance conditions and employment schedules for specific levels of education. Moreover, conditions must be created to attract more women to higher education. The priority task of the government of the country is to improve the quality of life of women in poor regions, as well as the position of women in the education system of these regions in order to overcome the "gender asymmetry".

\section{References}

1. G.G. Sillaste, Higher Edu Rus, 3, 122-133 (2004)

2. Y. Akyüz, Osmanlı Son Döneminde Kızların Eğitimi ve Öğretmen Faika Ünlüer'in Yetişmesi ve Meslek Hayatı [The Education of Girls in the Last Ottoman Period and the Upbringing and Professional Life of Teacher Faika Ünler] (1999). Accessed on: October 14, 2021. [Online]. Available: http://dhgm.meb.gov.tr/yayimlar/dergiler/Milli_Egitim_Dergisi/143/1.htm

3. Y. Akyüz, Tanzimat'tan Cumhuriyet'e Türkiye'de Toplumsal Değişme ve Kadın Eğitimi [Social Change and Education of Woman in Turkey from Tanzimat (Reformation) to Republic], in A.M. Tuncoku (ed), Toplumsal Gelişmede Türk ve Japon Kadınının Eğitimi [Women's Education in Turkey and Japan for Social Development], 1-59 (Ankara, 2011)

4. Y. Akyüz, Türk Eğitim Tarihi M.Ö. 1000 - M.S. 2016 [History of Turkish Education B.C. 1000 - A.D. 2016] (Pegen Akademi, Ankara, 2018)

5. O. Yaşar, Int J Human Sci, 4(1), 1-35 (2007)

6. B. Çakmak, J Theatre Critic Drama, 1(18), 51-88 (2011)

7. R. Eşkinat, Türkiye'de Sivil Toplum Örgütlerinin Kadınların Eğitimine Katkısı [Contribution of Civil Society Organizations in Turkey to Women's Education], in A.M. Tuncoku (ed), Toplumsal Gelişmede Türk ve Japon Kadınının Eğitimi [Women's Education in Turkey and Japan for Social Development], 259-279 (Ankara, 2011)

8. R. Eşkinat, J Faculty Law Anadolu Univ, 2(3), 267-282 (2016) 
9. H. Aydın, Curr Res Soc Sci, 1(3), 84-96 (2015)

10. H. Tor, E. Ağl1, J Res Edu Teach, 5(9), 67-74 (2016)

11. Z.Z. Güven, Eğitim ve Kadın İşgücü [Education and Women's Labor Force], in B. Afşar, B. Büyükdoğan (eds), Dünyada Kadın İşücüKadın İşgücü ve Disiplinlerarası Bir Bakış [A Comprehensive and Interdisciplinary Overview of the Women's Labor Force in the World], 115-124 (Gazi Kitabevi, Ankara, 2016)

12. N. Sargın, Ĕgitim ve Kadın İsgü̈cü [Education and Women's Labor Force], in B. Afşar, B. Büyükdoğan (eds), Türkiye'de Kadın ve Eğitim. Kadın İşgücü ve Disiplinlerarası Bir Bakış [A Comprehensive and Interdisciplinary Overview of the Women's Labor Force in the World], 199-208 (Gazi Kitabevi, Ankara, 2016)

13. G.G. Sillaste, Gendernaya sotsiologiya i rossiiskaya deistvitelnost [Gender Sociology and Russian Reality] (Alfa-M, NIC INFRA-M, Moscow, 2016)

14. G.G. Sillaste, Human South Rus, 6(5), 48-62 (2017)

15. World Bank, Europe and Central Asia Economic Update, Spring 2021: Data, Digitalization, and Governance (Washington, 2021). https://doi.org/10.1596/978-1-4648-1698-7

16. Reiting stran mira po urovnyu gendernogo neravenstva [Gender Inequality Index] (2021). Accessed on: October 14, 2021. [Online]. Available: https:/gtmarket.ru/ratings/gender-inequality-index

17. Reiting stran mira po indeksu urovnya obrazovaniya [Ranking of countries in the world by education level] (2021). Accessed on: October 14, 2021. [Online]. Available: https://gtmarket.ru/ratings/education-index

18. OECD, TALIS 2018 Results (Volume I): Teachers and School Leaders as Lifelong Learners (OECD Publishing, Paris, 2019). https://doi.org/10.1787/1d0bc92a-en

19. OECD, TALIS 2018 Results (Volume II): Teachers and School Leaders as Valued Professionals (OECD Publishing, Paris, 2020). https://doi.org/10.1787/19cf08df-en

20. OECD. Positive, High-achieving Students? What Schools and Teachers Can Do (OECD Publishing, Paris, 2021). https://doi.org/10.1787/3b9551db-en

21. Turkey. Overview of the education system (2020). Accessed on: October 14, 2021. [Online]. Available:

https://gpseducation.oecd.org/CountryProfile?primaryCountry=TUR\&treshold=10\&to pic $=\mathrm{EO}$

22. N.V. Bondarenko et al., Pokazateli obrazovaniya: 2020: Statisticheskii sbornik [Education indicators: 2020: Statistical collection] (NRU HSE, Moscow, 2020)

23. E.E. Dinçsoy, O.M. Dinçsoy, Japonya ve Türkiye'de Kadının Eğitimi ve İstihdamı [Women's Education and Employment in Japan and Turkey], in A.M. Tuncoku (ed), Toplumsal Gelişmede Türk ve Japon Kadınının Eğitimi [Women's Education in Turkey and Japan for Social Development], 75-89 (Ankara, 2011)

24. Gender ko'rsatkichlari raqamlarda [Gender Statistics of Uzbekistan] (2021). Accessed on: October 14, 2021. [Online]. Available: https://gender.stat.uz 